\title{
Effect of Mutations in Pisum sativum L. Genes Blocking Different Stages of Nodule Development on the Expression of Late Symbiotic Genes in Rhizobium leguminosarum bv. viciae
}

\author{
Vera A. Voroshilova, ${ }^{1}$ Bert Boesten, ${ }^{2}$ Viktor E. Tsyganov, ${ }^{1}$ Alexey Y. Borisov, ${ }^{1}$ Igor A. Tikhonovich, ${ }^{1}$ \\ and Ursula B. Priefer ${ }^{2}$
${ }^{1}$ All-Russia Research Institute for Agricultural Microbiology, Podbelsky chaussee 3, St.-Petersburg, Pushkin 8, 196608, Russia; ' $O$ ekologie des Bodens, RWTH Aachen, Worringer Weg 1, D-52056 Aachen, Germany \\ Accepted 7 December 2000.
}

In this report, the expression of late symbiotic genes $(f n r N$, fixN, and nifA) of Rhizobium leguminosarum bv. viciae was studied in nodules of mutant pea lines blocked at four successive stages of nodule development. Bacterial gene expression was analyzed in situ with transcriptional gus $A$ reporter gene fusions. As a control, a constitutively expressed gusA gene was included. In the nodules of Nop (nodule persistence) mutants (mutant in gene sym13), which had not yet exhibited signs of premature senescence, the expression patterns observed were identical to those in wild-type nodules. Normal expression of fusions also occurred in nodules defective at the infection droplet differentiation stage (mutant in gene sym40) in which bacteria are endocytosed, but infection threads and infection droplets are hypertrophied. In contrast, in Itn $^{-}$(infection thread formation inside the nodule tissue) mutants (mutant gene sym33), in which there is no endocytosis of bacteria, expression of the constitutive fusion was only in infection threads and no activity was shown for the other fusions. From this it can be concluded that functionality of the plant gene Sym33, i.e., bacterial endocytosis, is a prerequisite for the expression of late symbiotic genes in the microsymbiont. No morphologically distinct interzone IIIII could be detected in nodules blocked at the bacteroid differentiation stage (mutants in gene sym31). The constitutive fusion was expressed equally throughout the nodule tissue (except for the meristem), and the activity of fusions to late symbiotic genes increased gradually with a maximal expression level at the base of the nodule. This is consistent with an altered oxygen barrier previously reported for these nodules. By including double mutants, earlier results on sequential functioning of gene pairs sym33sym40 and sym31-sym13 could be confirmed and it could be demonstrated that the developmental epistasis found at the morphological level also is reflected in the expression pattern of late symbiotic genes in the microsymbiont.

Corresponding author: A. Y. Borisov; Telephone: +7 81247043 92; Fax: +7 81247043 62; E-mail: biotec@ peterlink.ru
Legume plants are able to enter nitrogen-fixing symbioses with bacteria of the genera Rhizobium, Sinorhizobium, Azorhizobium, Mesorhizobium, and Bradyrhizobium species. This symbiotic association is a very useful model system for studying general mechanisms of plant-microbe interactions because the development of the symbiotic organs, the root nodules, depends on molecular signal exchange between the two partners and on the coordinate expression of bacterial and plant genes (Schultze and Kondorosi 1998).

The role of rhizobial genes in these interactions has been studied intensively and, as a result, a number of bacterial genes involved in nodulation and symbiotic nitrogen fixation have been identified. The group of nod genes is required for the synthesis and secretion of factors (lipochitooligo-saccharides) that induce plants to form nodules (Schultze and Kondorosi 1998). The structure of these molecules determines the host specificity of nodulation (Schultze and Kondorosi 1996). The group of nif genes is necessary for the synthesis of the nitrogenase enzyme complex, whereas fix genes are essential for bacteria to function in the symbiotic state (Fisher 1994; Fisher and Long 1992; Van Rhijn and Vanderleyden 1995).

On the plant side, approximately 100 symbiotic genes have been described during the last 15 years in more than 10 legume species (Benaben et al. 1995; Borisov et al. 1999; Caetano-Anollés and Gresshoff 1991; Devine and Kuykendall 1996; Duc 1995; Esser-Monning et al. 1995; Kiss et al. 1995; Pedalino and Kipe-Nolt 1993; Pedalino et al. 1993; Pemberton et al. 1990; Penmetsa and Cook 1997; Sagan and Duc 1996; Sagan et al. 1995; Szczyglowski et al. 1998). In Pisum sativum L., more than 40 symbiotic genes have been identified to date (Borisov et al. 1999). Many pea mutants have been characterized at the morphological level (Borisov et al. 1992; Guinel and Sloetjes 2000; Kneen and LaRue 1984; Kneen et al. 1990; Markwei and LaRue 1992; Morzhina et al. 2000; Novák et al. 1995; Postma et al. 1988a; Postma et al. 1988b; Postma et al. 1990; Sagan et al. 1993; Sagan et al. 1994; Tsyganov et al. 1998; Tsyganov et al. 1999) and a block at a specific stage of nodule development has been shown for all of them. The mutants were classified with the phenotypic codes suggested by Vincent (1980) and modified by Borisov 
et al. (1999), Caetano-Annolés and Gresshoff (1991), and Tsyganov et al. (1998). On this basis, the process of nodule development was dissected into eight developmental stages: root hair curling (Hac), infection thread growth initiation (Iti), infection thread growth in root hair cells (Ith), infection thread growth inside root cortical tissue (Itr), infection thread differentiation inside nodule tissue (Itn), infection droplet differentiation (Idd), bacteroid differentiation (Bad), and nodule persistence (Nop) (Borisov et al. 1999).

The present study was aimed at the analysis of the expression of late symbiotic genes in Rhizobium leguminosarum bv. viciae in nodules of pea mutants blocked at four of these developmental stages: Itn, Idd, Bad, and Nop. To our knowledge, this is the first investigation of this kind. As a representative for late symbiotic genes, we chose the fixNOQP operon, which encodes a bacteroid-specific cbb3-type oxidase system essential for nitrogen fixation (Schlüter et al. 1995; Schlüter et al. 1997). This operon is duplicated in strain VF39 ( ixN $\mathrm{N}$ and fixNd), and both copies are induced under free-living microaerobic conditions and in the nitrogen-fixation zone (histological zone III) of the root nodule (Schlüter et al. 1997). In addition, nifA-gusA and $f n r N-g u s A$ fusions were included in the study. NifA is the central nitrogen-fixation activator protein (Morett and Buck 1989; Morett et al. 1988) and FnrN is a regulator, which is necessary for induction of the fixNOQP operons (Colonna-Romano et al. 1990; Patschkowski et al. 1996; Schlüter et al. 1992).

\section{RESULTS}

\section{Expression of bacterial fusions in wild-type nodules.}

All three fusions behaved identically. Only the results obtained with the fixN-gusA fusions are presented below.

Inoculated plants of all wild-type lines (SGE, Sparkle, and Sprint-2) formed pink nodules. Expression of the constitutive fusion (Fig. 1E) occurred in all histological zones defined by Vasse et al. (1990), except for zone I (meristem), which does not contain bacteria. Zone IV, the area in which the symbiotic compartments are degraded, was not observed at this stage of development. The expression pattern of the fixN-gusA fusion (Fig. 1J), i.e., induction in interzone II-III and strong expression in the symbiotic zone (III) confirmed results described earlier for Vicia hirsuta nodules (Schlüter et al. 1997).

\section{Expression of bacterial fusions \\ in nodules blocked at the Nop stage.}

Plants of line E135f (sym13) form small, greenish nodules, which develop all histological zones but are characterized by premature appearance of zone IV, i.e., the early degradation of symbiotic structures (Kneen et al. 1990). Figure 1D and I shows the expression of the bacterial fusions in mutant nodules that do not show signs of premature senescence and, therefore, exhibits the same expression pattern as wild-type nodules (compare with Fig. 1E and J, respectively). In nodules that already had developed a degradation zone, the staining was mosaic-like in the basal part as a result of the destruction of symbiotic compartments and bacteroids (data not shown).

\section{Expression of bacterial fusions \\ in nodules blocked at the Bad stage.}

Plants of line Sprint-2Fix (sym31) form white, nonfixing nodules. The plant cells are infected but contain morphologi- cally undifferentiated "juvenile" bacteroids (Borisov et al. 1992; Borisov et al. 1997a; Sherrier et al. 1997). In these mutant nodules, a morphologically distinct interzone II-III was not observed. The constitutive fusion was expressed equally throughout the nodule tissue, except for the meristem (Fig. 1C). Activity of the fixN-gusA fusion increased gradually with a maximal expression level at the base of the nodule (Fig. 1H), indicating that the symbiotic state of bacteria in which this fusion is induced was reached later, i.e., in deeper nodule cell layers (compare with the wild-type nodule, Fig. $1 \mathrm{~J}$ ). The double mutant RBT (sym13, sym31) (Borisov et al. 1997a) showed the same expression pattern (data not shown).

\section{Expression of bacterial fusions}

in mutant nodules blocked at the Idd stage.

Plant mutant line SGEFix ${ }^{-}-1$ (sym40) is characterized by the formation of abnormal, hypertrophied infection threads and infection droplets and as a result by abnormal endocytosis (Tsyganov et al. 1998). The expression of the constitutive and fixN-gusA fusions is shown in Figure 1B and G, respectively. The expression of the respective bacterial fusions is more or less identical to that observed in wild-type nodules, i.e., the constitutive fusion is expressed in zone II (the infection zone) and in zone III cells, which contain endocytosed bacteria (Fig. 1B), the fixN-gusA fusion is induced in interzone II-III and expressed throughout zone III (Fig. 1G).

\section{Expression of bacterial fusions in mutant nodules blocked at the Itn stage.}

As described earlier (Tsyganov et al. 1998), plants of the mutant line SGEFix--2 (sym33) form two types of nodules: white ones in which the infection threads do not form infection droplets and thus no endocytosed bacteria can be observed (except for some few plant cells) and pinkish ones in which the majority of nodule cells contain endocytosed bacteria, which are subject to premature degradation. Both types of nodules also could be observed after inoculation with the bacterial fusion strains. In contrast, plants of line RisFixU, carrying the same mutation (sym33) and the double mutant RBT3 (sym33, sym40) only formed white nodules in which endocytosed bacteria could not be detected. Figure 1A shows the expression of the constitutive fusion in nodules of mutant line RisFixU (sym33) where only the infection threads are stained. Expression of the fixN-gusA fusion could not be observed in this mutant (Fig. 1F). In nodules of mutant SGEFix $^{-}-2$ (sym33), however, expression of this fusion also occurred in those few cells where endocytosed bacteria could be found (Fig. 1K).

\section{DISCUSSION}

In the present study, a new approach was undertaken to investigate the expression of genes in the microsymbiont as a function of certain genes in the macrosymbiont. For this purpose, gusA transcriptional fusions of late rhizobial symbiotic genes ( $f i x N$, fnrN, nifA) were analyzed in pea mutants blocked at four different stages of nodule development. The absence of gusA activity in nodules of plant lines mutated in gene sym33, which is characterized by the lack of endocytosed bacteria, documents that the expression of late rhizobial sym genes such as fixN, fnrN, and nifA depends on the func- 
tion of the plant gene Sym33, which controls bacterial endocytosis into the plant cell cytoplasm. This is confirmed by their expression in rare nodule cells containing bacteroids (SGEFix $\left.{ }^{-}-2\right)$ (Fig. 1K).
In addition, it was shown that the phenotypic manifestation of a mutation in gene sym33 depends on genetic background. For instance, the phenotype of mutant SGEFix ${ }^{-}-2$ (sym33) obtained on the background of line SGE is leaky (some cells
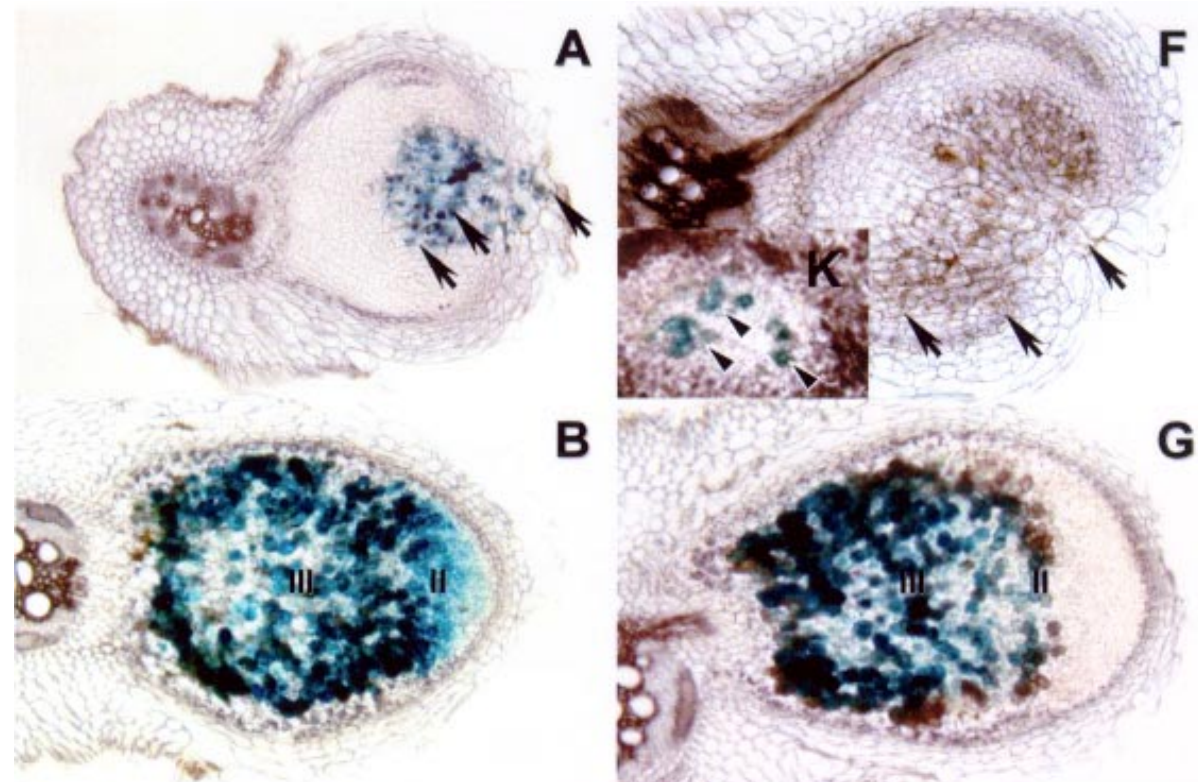

B
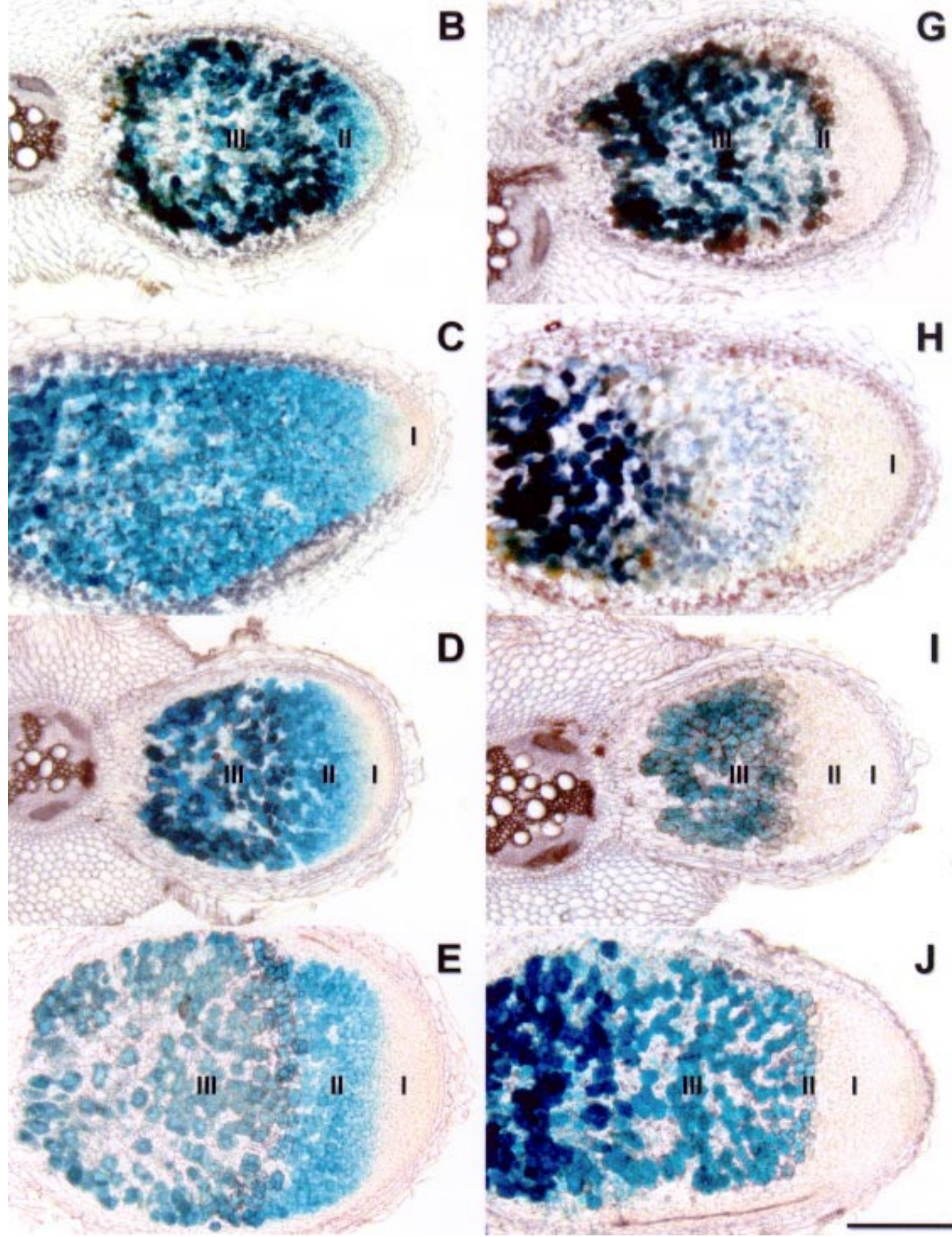

H

D

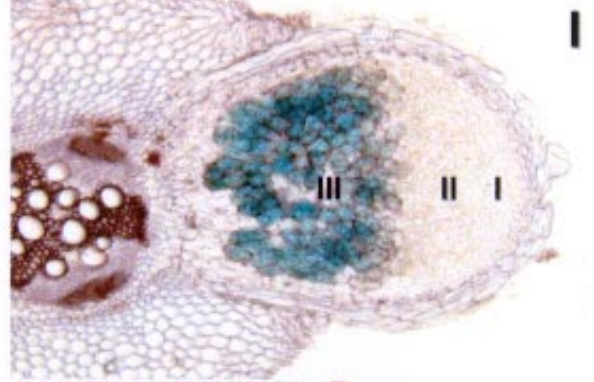

$\mathbf{E}$

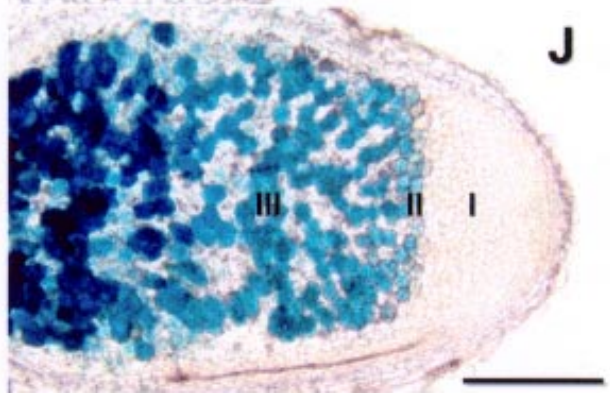

Fig. 1. Expression patterns of a constitutively expressed gusA gene (Tn5-gusA) and a gusA transcriptional reporter gene fusions to late bacterial symbiotic genes (represented by fixN-gusA) in pea mutant nodules blocked at different developmental stages. A-E, Constitutive gusA fusion. F-K, fixN-gusA fusion. A and F, RisFixU (sym33). K, SGEFix ${ }^{-} 2$ (sym33). B and G, SGEFix ${ }^{-}-1$ (sym40). C and H, Sprint-2Fix ${ }^{-}$(sym31). D and I, E135f (sym13). $\mathbf{E}$ and J, Wild-type line SGE; I-III: nodule histological zones (marked where identifiable). Arrows: infection threads; arrowheads: cells with endocytosed bacteria in nodules of line SGEFix ${ }^{-}-2$ (sym33); bar $=0.4 \mathrm{~mm}$. 
have endocytosed bacteria), whereas mutant RisFixU (sym33) derived from $P$. sativum L. cv. Finale has a stable phenotype (complete lack of endocytosis). Further phenotypic analysis is necessary to uncover the function of this gene and the nature of both mutations.

The differences observed in the expression pattern of late bacterial sym genes in nodules of pea lines carrying mutations in gene sym 31 as compared with wild-type plants (absence of a morphologically distinct interzone II-III and a gradually increasing expression toward the base of the nodule) can be explained by the fact that, in this mutant, the oxygen barrier appears to be altered. Instead of an abrupt drop, Romanov et al. (1995) showed that a slow and continual decrease in the oxygen concentration and a higher minimal level in Sprint2 Fix $^{-}$(sym31) mutant nodules so that it can be assumed that the oxygen concentration necessary for the induction of late rhizobial sym genes is reached gradually only in the deeper cell layers of the nodule. At the same time, this observation confirms that oxygen is one of the major physiological signals for the expression these genes in Rhizobium spp. (Soupene et al. 1995). In addition, the fact that expression of late rhizobial symbiotic genes does occur in Sprint-2Fix ${ }^{-}$(sym31) mutant nodules, in bacteroids that do not differ from bacteria in infection threads (Borisov et al. 1997a) demonstrates that complete differentiation of bacteroids is not necessary for induction of this group of bacterial genes.

By including double mutants, we confirmed previous results on the sequential functioning of the gene pairs sym33-sym40 (Borisov et al. 1997b) and sym31-sym13 (Borisov et al. 1997a) and demonstrate that the developmental epistasis found with respect to the structure of nodule symbiotic compartments also is reflected in the expression pattern of late symbiotic genes in the microsymbiont.

\section{MATERIALS AND METHODS}

\section{Plant material.}

Pea ( $P$. sativum L.) mutant lines used in this study and their parental lines are listed in Table 1.

\section{Bacterial strains.}

The transcriptional fusion strains used in this study were derived from Rhizobium leguminosarum bv. viciae VF39SM (Priefer 1989). For constitutive gusA expression, a derivative that contained a Tn5-gusA insertion in the genome that was verified to be expressed constitutively was chosen. The fixNgusA fusion strain carried a gusA cassette fused to the $5^{\prime}$ part of fixNc and integrated into the fixNOQP operon on plasmid $\mathrm{C}$ (Schlüter et al. 1997). The fnrN-gusA fusion was constructed with an EcoRV restriction site in the center of $f n r N$ (T. Patschkowski, unpublished). The nifA-gusA fusion was constructed as described by Patschkowski et al. (1996).

Bacteria were grown on TY agar medium (Beringer 1974) at $28^{\circ} \mathrm{C}$. If necessary, antibiotics were added at concentrations as described by Patschkowski et al. (1996).

\section{Plant inoculation.}

$P$. sativum seeds were surface sterilized with concentrated sulfuric acid (30 min at room temperature). Bacteria were taken from plates, suspended in water $\left(10^{8}\right.$ to $10^{9}$ cells per $\mathrm{ml}$ ), and $1 \mathrm{ml}$ per seed was added at the moment of sowing the seeds in sterile vermiculite as a substrate. Nitrogen-free nutrient solution was used as previously described (Borisov et al. 1997a).

Plants were grown in growth chambers under the following conditions (day/night): 16 and $8 \mathrm{~h}, 21$ and $19^{\circ} \mathrm{C}$, relative humidity of $75 \%$, and photon irradiance of $490 \mathrm{mE} / \mathrm{m}^{2}$ per s.

\section{Histochemical staining and microscopy.}

Nodules from mutant and wild-type plants were harvested 4 weeks after inoculation. They were sliced into $70 \mu \mathrm{m}$ sections by means of a VT $1000 \mathrm{~S}$ vibratom (Leica, Wezler, Germany). Sections were stained in $50 \mathrm{mM}$ sodium-phosphate buffer, $\mathrm{pH}$ 7.0, containing $0.1 \%$ Triton, $5 \mathrm{mM} \mathrm{K} \mathrm{K}_{3} \mathrm{Fe}\left(\mathrm{CN}_{6}\right), 5 \mathrm{mM}$ $\mathrm{K}_{4} \mathrm{Fe}\left(\mathrm{CN}_{6}\right)$, and $0.02 \%$ 5-bromo-4-chloro-3-indolyl- $\beta$-D-glucuronic acid. In the case of the constitutive gusA fusion, the nodules were stained for $30 \mathrm{~min}$, whereas nodules formed by the other fusion strains were incubated overnight. After staining, samples were fixed in $1.25 \%$ glutaraldehyde in $0.1 \mathrm{M}$ phosphate buffer for $1 \mathrm{~h}$ and subsequently rinsed in water.

For light microscopy, sections were transferred onto glass slides. Photographs were taken with a Om-4 camera (Olympus, Hamburg, Germany) mounted onto an Olympus BX50 light microscope.

\section{ACKNOWLEDGMENTS}

We are very grateful to L. E. Dvoryaninova and M. Krämer for their excellent technical assistance. B. Kosier is thanked for editorial help. This study was supported by grants from the Volkswagen Stiftung (I/72 935) and the Russian Foundation for Basic Research (98-04-49883).

Table 1. Plant material used in the study

\begin{tabular}{|c|c|c|}
\hline Lines & Phenotype & References \\
\hline SGE & Wild-type line & Kosterin and Rozov 1993 \\
\hline SGEFix ${ }^{-}-1(\operatorname{sym} 40)$ & Abnormal (hypertrophied) infection droplet formation $\left(\mathrm{Idd}^{-}\right)$ & Tsyganov et al. 1998 \\
\hline SGEFix ${ }^{-}-2($ sym 33$)$ & No endocytosis of bacteria $\left(\operatorname{Itn}^{-}\right)$, leaky phenotype & Tsyganov et al. 1998 \\
\hline RBT3 (sym33, sym40) & No endocytosis of bacteria $\left(\mathrm{Itn}^{-}\right)$ & Borisov et al. 1997b \\
\hline Sparkle & Wild-type line & Kneen et al. 1990 \\
\hline E135f (sym13) & Early degradation of symbiotic compartments $\left(\mathrm{Nop}^{-}\right)$ & Kneen et al. 1990 \\
\hline Sprint -2 & Wild-type line & Berdnikov et al. 1989 \\
\hline Sprint-2Fix ${ }^{-}(\operatorname{sym} 31)$ & No bacteroid differentiation $\left(\mathrm{Bad}^{-}\right)$ & Borisov et al. 1997a \\
\hline RBT (sym13, sym31) & No bacteroid differentiation $\left(\mathrm{Bad}^{-}\right)$ & Borisov et al. 1997a \\
\hline Finale & Wild-type line & Engvild 1987 \\
\hline RisFixU $(\operatorname{sym} 33)^{\mathrm{a}}$ & No endocytosis of bacteria $\left(\mathrm{Itn}^{-}\right)$ & Engvild 1987; this study \\
\hline
\end{tabular}

${ }^{\mathrm{a}}$ Gene symbol for the gene identified in this mutant line was assigned according to G. Duc and M. Sagan, personal communication. Mutant phenotype was described during present study. 


\section{LITERATURE CITED}

Benaben, V., Duc, G., Lefebre, V., and Huguet, T. 1995. TE7, an inefficient symbiotic mutant of Medicago truncatula Gaertn. cv. Jemalong. Plant Physiol. 107:53-62.

Berdnikov, V. A., Rozov, S. M., and Bogdanova, V. S. 1989. Construction of a series of laboratory pea lines. Pages 26-27 in: Abstracts of Conference on Genetics, Vol. II. Genetics of Plant, Kiev, U.S.S.R.

Beringer, J. E. 1974. R factor transfer in Rhizobium leguminosarum. J. Gen. Microbiol. 84:188-198.

Borisov, A. Y., Morzhina, E. V., Kulikova, O. A., Tchetkova, S. A., Lebsky, V. K., and Tikhonovich, I. A. 1992. New symbiotic mutants of pea (Pisum sativum L.) affecting either nodule initiation or symbiosome development. Symbiosis 14:297-313.

Borisov, A. Y., Rozov, S. M., Tsyganov, V. E., Morzhina, E. V., Lebsky, V. K., and Tikhonovich, I. A. 1997a. Sequential functioning of Sym-13 and Sym-31, two genes affecting symbiosome development in root nodules of pea (Pisum sativum L.). Mol. Gen. Genet. 254:592-598.

Borisov, A. Y., Lebsky, V. K., Morzhina, E. V., Rozov, S. M., Tsyganov, V. E., and Tikhonovich, I. A. 1997b. Study of pea (Pisum sativum L.) symbiotic gene interactions using a panel of lines carrying two Fix mutations and a comparative study of their nodule ultrastructure. Page 345 in: Nitrogen Fixation for the 21st Century. C. Elmerich, A. Kondorosi, and W. E. Newton, eds. Kluwer Academic Publishers, Dordrecht, The Netherlands.

Borisov, A. Y., Jacobi, L. M., Lebsky, V. K., Morzhina, E. V., Tsyganov, V. E., Voroshilova, V. A., and Tikhonovich, I. A. 1999. Genetic system controlling development of nitrogen-fixing nodules and arbuscular mycorrhiza. Pisum Genet. 31:40-44.

Caetano-Anollés, G., and Gresshoff, P. M. 1991. Plant genetic control of nodulation. Annu. Rev. Microbiol. 45:345-382.

Colonna-Romano, S., Arnold, W., Schlüter, A., Boistard, P., Pühler, A., and Priefer, U. B. 1990. An Fnr-like protein encoded in Rhizobium leguminosarum biovar viciae shows structural and functional homology to Rhizobium meliloti fixK. Mol. Gen. Genet. 223:138-147.

Devine, T. E., and Kuykendall, L. D. 1996. Host genetic control of symbiosis in soybean (Glycine max L.). Plant Soil 186:173-187.

Duc, G. 1995. Mutagenesis of faba bean (Vicia faba L.) and the identification of five different genes controlling no nodulation, ineffective nodulation or supernodulation. Euphytica 83:147-152.

Engvild, K. J. 1987. Nodulation and nitrogen fixation mutants of pea (Pisum sativum). Theor. Appl. Genet. 74:711-713.

Esser-Monning, K., Roskothen, P., and Röbbelen, G. 1995. Two host genes in Vicia faba for nodulation deficiency with strain specificity for Rhizobium leguminosarum. Plant Breed. 114:363-365.

Fisher, H. M. 1994. Genetic regulation of nitrogen-fixation in rhizobia. Microbiol. Rev. 58:352-386.

Fisher, H. M., and Long, S. R. 1992. Rhizobium-plant signal exchange. Nature 357:655-660.

Guinel, C. F., and Sloetjes, L. L. 2000. Ethylene is involved in the nodulation phenotype of Pisum sativum R50 (sym16), a pleiotropic mutant that nodulates poorly and has pale green leaves. J. Exp. Bot. 51:885-894.

Kiss, G. B., Kalo, P., Csanadi, G., Folfoldi, K., Kiss, P., and Endre, G. 1995. Map based cloning system in Medicago suitable for isolating genes involved in leaf morphogenesis, nodule formation and effectiveness of nitrogen fixation. Pages 437-442 in: Nitrogen Fixation: Fundamentals and Applications. I. A. Tikhonovich, N. A. Provorov, V. I. Romanov, and W. E. Newton, eds. Kluwer Academic Publishers, Dordrecht, The Netherlands.

Kneen, B. E., and LaRue, T. A. 1984. Nodulation resistant mutant of Pisum sativum L. J. Hered. 75:238-240.

Kneen, B. E., LaRue, T. A., Hirsch, A. M., Smith, C. A., and Weeden, N. F. 1990. sym-13: A gene conditioning ineffective nodulation in Pisum sativum. Plant Physiol. 94:899-905.

Kosterin, O. E., and Rozov, S. M. 1993. Mapping of the new mutation $b l b$ and the problem of integrity of linkage group I. Pisum Genet. 25:27-31.

Markwei, C. P., and LaRue, T. A. 1992. Phenotypic characterization of sym8 and sym 9 genes conditioning non-nodulation in Pisum sativum "Sparkle." Can. J. Microbiol. 38:548-554.

Morett, E., and Buck, M. 1989. In vivo studies on the interaction of RNA polymerase $\left(\sigma^{54}\right)$ with the Klebsiella pneumoniae and Rhizobium meliloti nifH promoters: The role of NifA in the formation of an open promoter complex. J. Mol. Biol. 210:65-77.

Morett, E., Cannon, W., and Buck, M. 1988. The DNA-binding domain of the transcriptional activator protein NifA resides in its carboxy terminus, recognises the upstream activator sequences of nifA promoters and can be separated from the positive control function of NifA. Nucl. Acids Res. 16:11469-11488.

Morzhina, E. V., Tsyganov, V. E., Borisov, A. Y., Lebsky, V. K., and Tikhonovich, I. A. 2000. Four developmental stages identified by genetic dissection of pea (Pisum sativum L.) root nodule morphogenesis. Plant Sci. 155:75-83

Novák, K., Pešina, K., Nebesárová, J., Škrdleta, V., Lizá, L., and Našinec, V. 1995. Symbiotic tissue degradation pattern in the ineffective nodules of three nodulation mutants of pea (Pisum sativum L.). Ann. Bot. 76:303-313.

Patschkowski, T., Schlüter, A., and Priefer, U.B. 1996. Rhizobium leguminosarum bv. viciae contains a second fnr/fixK-like gene and an unusual fixL homologue. Mol. Microbiol. 21:67-280.

Pedalino, M., and Kipe-Nolt, J. 1993. Common bean (Phaseolus vulgaris L.) mutants defective in root nodule formation. I. Physiological characterization. J. Exp. Bot. 44:1007-1014.

Pedalino, M., Kipe-Nolt, J., Frusciante, L., and Monti, L. 1993. Common bean (Phaseolus vulgaris L.) mutants defective in root nodule formation. II. Genetic analysis. J. Exp. Bot. 44:1015-1020.

Pemberton, I. J., Smith, G. R., and Miller, J. C. 1990. Inheritance of ineffective nodulation in cowpea. Crop Sci. 30:568-571.

Penmetsa, R. V., and Cook, D. R. 1997. A legume ethylene-insensitive mutant hyperinfected by its rhizobial symbiont. Science 275:527-530.

Postma, J. G., Jacobsen, E., and Feenstra, W. J. 1988a. Experiments with mutants of pea (Pisum sativum L.). Pages 629-633 in: Nitrogen Fixation: Hundred Years After. H. Bothe, F. J. de Bruijn, and W. E. Newton, eds. Gustav Fischer, Stuttgart, Germany.

Postma, J. G., Jacobsen, E., and Feenstra, W. J. 1988b. Three pea mutants with an altered nodulation studied by genetic analysis and grafting. J. Plant Physiol. 132:424-430.

Postma, J. G., Jager, D., Jacobsen, E., and Feenstra, W. J. 1990. Studies on a non-fixing mutant of pea (Pisum sativum L.). 1. Phenotypical description and bacteroid activity. Plant Sci. 68:151-161.

Priefer, U. B. 1989. Genes involved in lipopolysaccharide production and symbiosis are clustered on the chromosome of Rhizobium leguminosarum biovar viciae VF39. J. Bacteriol. 171:6161-6168.

Romanov, V. I., Gordon, A. J., Minchin, F. R., Witty, J. F., Scøt, L., James, C. L., Borisov, A. Y., and Tikhonovich, I. A. 1995. Anatomy, physiology and biochemistry of root nodules of Sprint-2Fix ${ }^{-}$, a symbiotically defective mutant of pea (Pisum sativum L.). J. Exp. Bot. 46:1809-1816.

Sagan, M., and Duc, G. 1996. Sym28 and Sym29, two new genes involved in regulation of nodulation in pea (Pisum sativum L.). Symbiosis 20:229-245.

Sagan, M., Huguet, T., Barker, D., and Duc, G. 1993. Characterization of two classes of non-fixing mutants of pea (Pisum sativum L.). Plant Sci. 95:55-66.

Sagan, M., Huguet, T., and Duc, G. 1994. Phenotypic characterization and classification of nodulation mutants of pea (Pisum sativum L.). Plant Sci. 100:59-70.

Sagan, M., Morandi, D., Tarenghi, E., and Duc, G. 1995. Selection of nodulation and mycorrhizal mutants in the model plant Medicago truncatula (Gaertn.) after X-ray mutagenesis. Plant Sci. 111:63-71.

Schultze, M., and Kondorosi, A. 1996. The role of Nod signal structures in the determination of host specificity in the Rhizobium-legume symbiosis. World J. Microbiol. Biotechnol. 12:137-149.

Schultze, M., and Kondorosi, A. 1998. Regulation of symbiotic root nodule development. Ann. Rev. Genet. 32:33-57.

Schlüter, A., Patschkowski, T., Unden, G., and Priefer, U. B. 1992. The Rhizobium leguminosarum FnrN protein is functionally similar to Escherichia coli Fnr and promotes heterologous oxygen-dependent activation of transcription. Mol. Microbiol. 6:3395-3404.

Schlüter, A., Rüberg, S., Krämer, M., Weidner, S., and Priefer, U. B. 1995. A homolog of the Rhizobium meliloti nitrogen fixation gene fixN is involved in the production of a microaerobically induced oxidase activity in the phytopathogenic bacterium Agrobacterium tumefaciens. Mol. Gen. Genet. 247:206-215.

Schlüter, A., Patschkowski, T., Quandt, J., Selinger, L. B., Weidner, S., Krämer, M., Zhou, L., Hynes, M. F., and Priefer, U. B. 1997. Functional and regulatory analysis of the two copies of the fixNOQP op- 
eron of Rhizobium leguminosarum strain VF 39. Mol. Plant-Microbe Interact. 10:605-616.

Sherrier, D. J., Borisov, A. Y., Tikhonovich, I. A., and Brewin, N. J. 1997. Immunological evidence for abnormal symbiosome development in nodules of the pea mutant line Sprint- $2 \mathrm{Fix}^{-}$(sym31). Protoplasma 199:57-68.

Soupene, E., Foussard, M., Boistard, P., Truchet, G., and Batut, J. 1995. Oxygen as a key developmental regulator of Rhizobium meliloti $\mathrm{N}_{2^{-}}$ fixation gene expression within the alfalfa root nodule. Proc. Natl. Acad. Sci. USA 92:3759-3763.

Szczyglowski, K., Shaw, R. S., Wopereis, J., Copeland, S., Hamburger, D., Kasiborski, B., Dazzo, F. B., and De Brujin, F. J. 1998. Nodule organogenesis and symbiotic mutants of the model Legume Lotus japonicus. Mol. Plant-Microbe Interact. 11:684-697.

Tsyganov, V. E., Morzhina, E. V., Stefanov, S. Y., Borisov, A. Y., Lebsky,
V. K., and Tikhonovich, I. A. 1998. New pea (Pisum sativum L.) genes sym33 and sym 40 control infection thread formation and root nodule function. Mol. Gen. Genet. 256:491-503.

Tsyganov, V. E., Voroshilova, V. A., Kukalev, A. S., Jacobi, L. M., Azarova, T. S., Borisov, A. Y., and Tikhonovich, I. A. 1999. Pea (Pisum sativum L.) genes Sym14 and Sym35 control infection thread growth initiation during development of symbiotic nodules. Russ. J. Genet. 34:1-9.

Van Rhijn, P., and Vanderleyden, J. 1995. The Rhizobium-plant symbiosis. Microbiol. Rev. 59:124-142.

Vasse, J., De Billy, F., Camut, S., and Truchet, G. 1990. Correlation between ultrastructural differentiation of bacteroids and nitrogen fixation. J. Bacteriol. 172:4295-4306.

Vincent, J. M. 1980. Factors controlling the legume-Rhizobium symbiosis. Pages 103-129 in: Nitrogen Fixation. E. Newton and W. H. Orme-Johnston, eds. University Park Press, Baltimore. 